\title{
Stomach contents of sperm whales Physeter macro- cephalus stranded in the North Sea 1990-1996
}

\author{
M. B. Santos ${ }^{1, *}$, G. J. Pierce ${ }^{1}$, P. R. Boyle ${ }^{1}$, R. J. Reid ${ }^{2}$, H. M. Ross ${ }^{2}$, I. A. P. Patterson ${ }^{2}$, \\ C. C. Kinze ${ }^{3}$, S. Tougaard ${ }^{4}$, R. Lick ${ }^{5}$, U. Piatkowski ${ }^{6}$, V. Hernández-García ${ }^{7}$ \\ ${ }^{1}$ Department of Zoology, University of Aberdeen, Tillydrone Avenue, Aberdeen AB24 2TZ, Scotland, UK \\ ${ }^{2}$ SAC Veterinary Science Division, Drummondhill, Stratherrick Road, Inverness IV2 4JZ, Scotland, UK \\ ${ }^{3}$ Zoologisk Museum, University Copenhagen, Universitetparken 15, DK-2100 København Ø, Denmark \\ ${ }^{4}$ The Fisheries and Maritime Museum, Tarphagevej 2, DK-6710 Esbjerg V, Denmark \\ ${ }^{5}$ Forschungs-und Technologiezentrum Westküste, Universität Kiel, Werftstr. 6, D-25671 Büsum, Germany \\ ${ }^{6}$ Institut für Meereskunde, Duesternbrooker Weg 20, D-24105 Kiel, Germany \\ ${ }^{7}$ Departamento de Biología Animal, Universidad de Las Palmas, E-35015 Las Palmas de Gran Canaria, Spain
}

\begin{abstract}
Stomach contents of 17 sperm whales Physeter macrocephalus stranded in Scotland and Denmark during 1990-96 were analysed. All were sub-adult or adult males and stranded between November and March. They had presumably entered the North Sea during their southward migration from feeding grounds in Arctic waters. Other studies indicate that the majority of the whales were apparently healthy. The diet of these whales was found to consist almost entirely of cephalopods, principally squid of the genus Gonatus (hereafter 'Gonatus', but probably G. fabricii, an oceanic species characteristic of Arctic waters). The other prey species identified were also mostly oceanic cephalopods: the squids Histioteuthis bonnellii, Teuthowenia megalops and Todarodes sagittatus and the octopus Haliphron atlanticus. Although these results are consistent with other recent studies in the area based on single stranded whales, they differ from results of work on whales caught during commercial whaling operations in Icelandic waters (1960s to 1980s) in that little evidence of predation on fish was found in the present study. Remains of single individuals of the veined squid Loligo forbesi, the northern octopus Eledone cirrhosa and the saithe Pollachius virens provided the only possible evidence of feeding in the North Sea. We infer that sperm whales do not enter the North Sea to feed. The timing, and large and uniform sizes of the Conatus species eaten (most had mantle lengths in the range 195 to $245 \mathrm{~mm}$ ), as estimated from measurements of the lower beaks, and the seasonality of the strandings is consistent with the whales having fed on mature squid, possibly spawning concentrations - as has recently been reported for bottlenose whales. Assuming that the diet recorded in this study was repre sentative of sperm whales during the feeding season, as much as $500000 \mathrm{t}$ of Gonatus could be removed by sperm whales in Norwegian waters each year and up to 3 times that figure from the eastern North Atlantic as a whole. Evidence from other studies indicates that Gonatus is an important food resource for a wide range of marine predators in Arctic waters.
\end{abstract}

KEY WORDS: Feeding ecology $\cdot$ Cetacea $\cdot$ Stranding $\cdot$ Gonatus $\cdot$ Cephalopoda

\section{INTRODUCTION}

Sperm whales Physeter macrocephalus L. are the largest toothed whales (Odontoceti), reaching lengths up to $18.3 \mathrm{~m}$ (Rice 1989). They are found in deep waters of all oceans, from the equator to the edges of the polar pack ice. Sperm whales are able to dive longer and deeper than any other cetacean. Dives last-

•E-mail:m.b.santos@abdn.ac.uk ing 60 to $90 \mathrm{~min}$ are frequently reported in the literature (Rice 1989) and there is evidence of dives down to $2000 \mathrm{~m}$ or more (Heezen 1957, Norris \& Harvey 1972 Clarke 1976, Rice 1978).

The social organisation of sperm whales is unique and complex. There is seasonal segregation of the sexes, with females and calves usually remaining in low latitudes all year round (Best 1979). In the northern hemisphere females and calves do not normally travel to latitudes above $40^{\circ}$ to $45^{\circ} \mathrm{N}$ (Berzin 1971), although 
there are occasional records from the North Atlantic (Harmer 1917, Fraser 1974, Berrow \& Rogan 1997, Smeenk 1997). 'Bachelor' and mature males undertake migrations to higher latitudes in spring/summer. In the northern hemisphere, they leave warm waters at the beginning of summer to reach feeding grounds on the perimeter of the polar zone, returning again in winter. During this southward migration, sperm whales are rarely seen on the continental shelf of the North Sea. More commonly they travel from the deep waters around Norway, Iceland and Greenland through the Rockall Trough (west of the British Isles) and the deep ocean basins west of the Iberian Peninsula (Smeenk \& Addink 1993)

There are no accurate figures for the total number of sperm whales in the world. Prior to modern (20th century) whaling, the world population of sperm whales is estimated to have been around 3 million and to have been reduced to less than 2 million (Rice 1989). Figures for the North Atlantic specifically are similarly uncertain. Gambell (1976) estimated a total population size of around 22000 sperm whales in the Atlantic. The 1982 Report of the International Whaling Commission (IWC) Sub-Committee on Sperm Whales gave tentative figures for the initial and current population of sperm whales in the North Atlantic (Gosho et al. 1984). Gunnlaugsson \& Sigurjónsson (1990) and Sigurjónsson \& Víkingsson (1992) gave more recent figures for the North Atlantic (9645 whales north of $50^{\circ} \mathrm{N}$ ).

Early studies of sperm whale diets made use of whales killed commercially and mainly consisted of analyses of single stomachs or observations of the food remains regurgitated by the whales after being harpooned (Beale 1839, Bennet 1840, Buchanan 1896, Millais 1906, Clarke 1956; see Berzin 1971 for a review). Studies carried out during the main period of commercial whaling in the 20th century, based on substantial sample sizes, provided extensive information on diets and feeding ecology throughout the world (see Kawakami 1980 and Rice 1989 for reviews).

Few of the early studies included any quantitative analysis of the food remains, but some areas (e.g. the Pacific) were studied in more detail than others. The results of these studies showed that, as a general rule, cephalopods are the most important food category, followed by fish (Kawakami 1980). Diet composition of sperm whales has been found to vary between regions, months, seasons and years, as well as between sexes and in relation to age or body length (Matthews 1938, Mizue 1951, Betesheva 1960, 1961, Tarasevich 1963, Berzin 1971, Clarke 1980, Kawakami 1980, Mikhalev et al. 1981, Rice 1989). Most studies have recorded squid as the most commonly eaten cephalopods, although octopods have also been found, typically in whales caught in coastal waters (Berzin 1971).
Sperm whales are recorded as taking a significant proportion of fish in their diet in North Atlantic and Arctic waters. Fish are recorded in sperm whale diets in some of the earliest studies from this area (Haldane 1905, Millais 1906, Murray \& Hjort 1912). In largerscale studies, Roe (1969) and Martin \& Clarke (1986) found fish to be the most numerous prey of male sperm whales caught off Iceland. Fish were also found to be important in the diet of sperm whales captured along the Gulf of Alaska and in the east Bering Sea (Okutani \& Nemoto 1964).

Following the IWC moratorium on all sperm whaling in 1985, most recent studies have been based mainly on analyses of stomach contents from single stranded whales (Clarke et al. 1980, Dong 1984, Pascoe et al. 1990, Viale et al. 1992, Ostrom et al. 1993, González et al. 1994, Lick et al. 1995, Clarke 1997, Clarke \& Pascoe 1997). Additionally, faecal samples have been collected from live sperm whales (Papastavrou et al. 1989, Whitehead et al. 1989, Smith \& Whitehead 1993, Whitehead 1996) and stable isotope ratios have been used to make inferences about feeding (Ostrom et al. 1993). There has been no large-scale study of sperm whale diets in Northern waters since Martin \& Clarke (1986).

Remains of sperm whales have been found in archaeological sites in Orkney dating from as early as the 9th or 10th century (Turner 1871) and strandings of this species in Northern Europe have been recorded in the literature since the 16th century (Smeenk 1997). The distinctive head and teeth of sperm whales, together with their size, make them one of the bestreported whale species (Evans \& Scanlan 1989). Most of the stranded whales for which sex has been determined have been adult or sub-adult males, but there have been a few cases of juveniles and one female stranding (Harmer 1917, Fraser 1974, Berrow \& Rogan 1997). Some stranding events have apparently involved whole groups of males (e.g. 11 males stranded in Orkney in December 1994 and 16 in Denmark in March 1996). The number of sperm whales stranded annually on North Sea coasts appears to have risen dramatically in the last 10 to $15 \mathrm{yr}$. In 1988 and 1990, recorded strandings in the area reached double figures for the first time this century. In 1994, 27 sperm whales were stranded. A further 25 strandings were recorded in 1996 (see Smeenk 1997 for a review of historical trends).

Recent single and mass strandings of sperm whales in Scotland and Denmark between 1990 and 1996 provided a unique opportunity to study the diet in an area for which few recent data are available and to compare the results from stranded whales with results from whales studied during whaling activities off Iceland in the 1960 s to 1980 s. 
In addition to describing and quantifying the diet, we address the question of whether sperm whales enter the North Sea to feed. We also estimate the amounts of different prey species eaten by sperm whales during the summer feeding season.

\section{METHODS}

Sample collection. All the sperm whales stranded in the Northeast Atlantic analysed in this study were males. The stranding locations are indicated in Fig. 1 and full details of total length, age, blubber thickness, etc. are given in Table 1. It was not possible to examine the whole gut of any of the whales since it was necessary to work alongside the local authorities responsible for disposing of the carcasses, who permitted opening of the carcasses only immediately before burial. Information on the age of the whales, based on growth increments in the teeth, was provided by Dr C. Lockyer.
Samples of the stomach contents from the sperm whales stranded in Denmark were collected under the auspices of the Danish Stranding Network run by the Fisheries and Maritime Museum of Esbjerg, the Zoological Museum, University of Copenhagen and the Danish Ministry of Environment and Energy.

No material could be obtained from other strandings during this period. No stomach contents were found in 4 sperm whales stranded in Belgium during 1994 (Thierry Jauniaux pers. comm.). A sperm whale stranded on 31 March 1997 in the Firth of Forth (Scotland) was fully dissected by staff at the Royal Scottish Museum but its stomach was reported to be empty (J. Herman pers. comm.).

Diet analysis. Cephalopod beaks were identified using published guides (Clarke 1980, 1986, PérezGándaras 1986) and a reference collection of oceanic cephalopod beaks. Standard measurements were taken on the lower beaks - rostral length (LRL) for decapods and hood length (LHL) for octopods (Clarke 1980 , 1986), using either callipers or a binocular microscope
Fig. 1. Northeast Atlantic and North Sea showing the locations of strandings in the present study, the distribution of Gonatus facrici including known spawning areas. Latitude and longitude are shown in degrees and the $200 \mathrm{~m}$ depth contour is indicated by the dashed line. The shaded areas show (Area 1) the distribution of Gonatus as reported by Kristensen (1983) and (Area 2) the extension to the distribution proposed by Bjørke (1995). Areas A-D mark the spawning areas proposed by Wiborg (1979): (A) west of Svalbard, (B) between Iceland and Jan Mayen, (C) off Vesterålen and (D) off Mrre. Sites of recent strandings (1-9, after Smeenk 1997) are also marked: (1) Sanday, Orkney Islands, (2) Nairn, (3) Cruden Bay, (4) Firth of Forth, (5) Koksijde and Nieuwpoort, (6) Romo Island, (7) Fanø, (8) Nymindegab and (9) Skagen

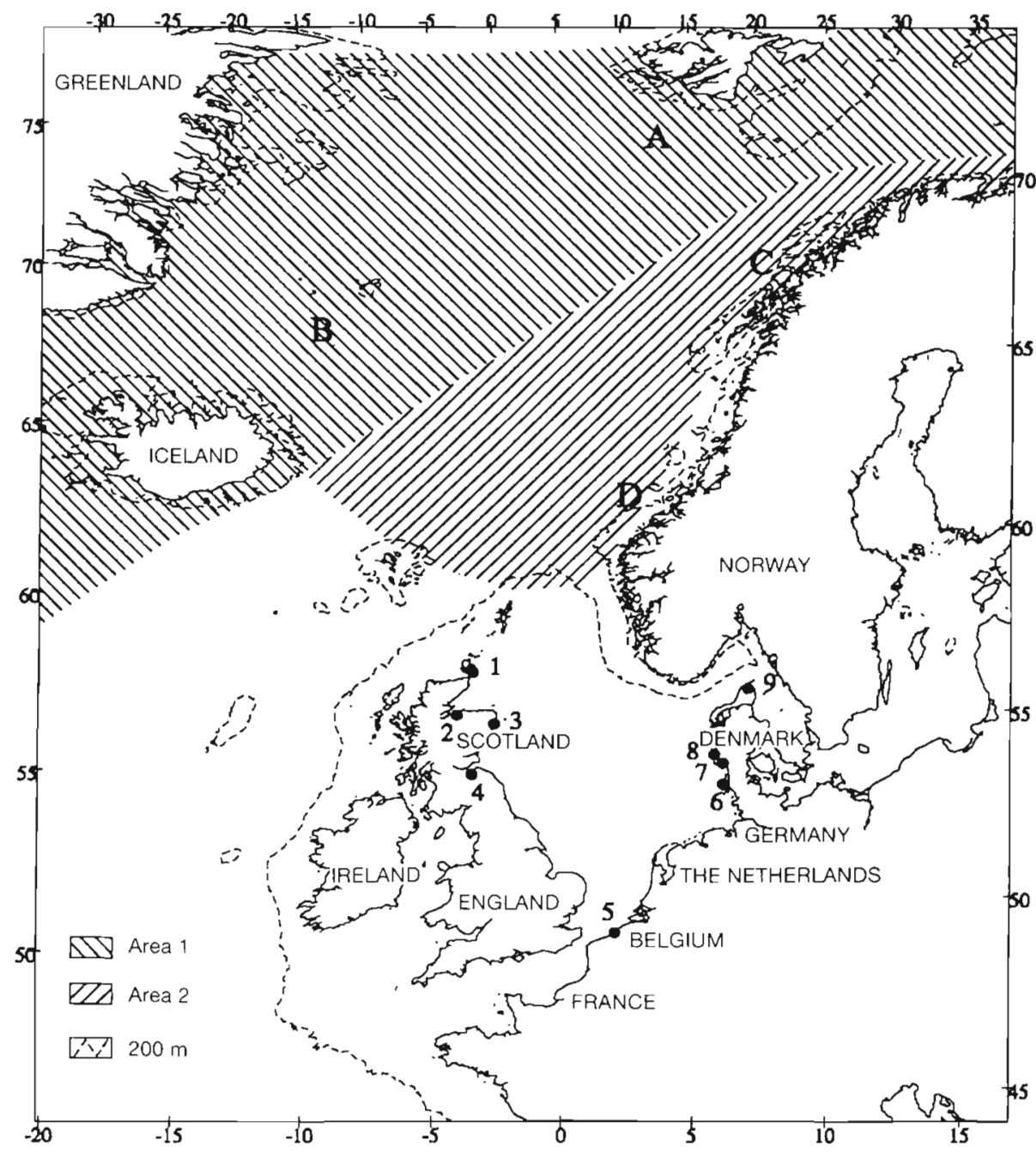


Table 1 Physeter macrocephalus. Stranding events in the Northeast Atlantic 1990 to 1996 from which stomach contents were analysed and stranding events during the same period in which stomachs were reported to be empty. Dates given as $d / m o / y r$

\begin{tabular}{|c|c|c|c|c|c|c|c|}
\hline Country & Date & Place & $\begin{array}{c}\text { No. } \\
\text { of whales }\end{array}$ & $\begin{array}{l}\text { Samples } \\
\text { collected }\end{array}$ & $\begin{array}{l}\text { Length } \\
(\mathrm{m})\end{array}$ & $\begin{array}{l}\text { Age } \\
(\mathrm{yr})\end{array}$ & $\begin{array}{l}\text { Blubber thickness } \\
\text { (mm) }\end{array}$ \\
\hline Scotland & $\begin{array}{l}07 / 12 / 94^{a} \\
23 / 03 / 95 \\
28 / 01 / 96^{\mathrm{a}} \\
31 / 03 / 97\end{array}$ & $\begin{array}{l}\text { Orkney Islands } \\
\text { Nairn } \\
\text { Cruden Bay } \\
\text { Firth of Forth }\end{array}$ & $\begin{array}{r}11 \\
1 \\
6 \\
1\end{array}$ & $\begin{array}{l}4 \\
1 \\
5 \\
0^{\text {b }}\end{array}$ & $\begin{array}{c}12-13.4 \\
13.7 \\
12.1-13.75 \\
15.20\end{array}$ & $\begin{array}{c}20-25 \\
20-25 \\
20-25 \\
42\end{array}$ & $\begin{array}{l}95-135 \\
120-140\end{array}$ \\
\hline Denmark & $\begin{array}{l}17 / 11 / 90 \\
01 / 12 / 91 \\
25 / 01 / 96 \\
27 / 03 / 96^{d}\end{array}$ & $\begin{array}{l}\text { Nymindegab } \\
\text { Fanø } \\
\text { Skagen } \\
\text { Rømø Island }\end{array}$ & $\begin{array}{c}1 \\
1 \\
1 \\
16\end{array}$ & $\begin{array}{l}1 \\
1 \\
1 \\
4\end{array}$ & $\begin{array}{c}11.85 \\
11.73 \\
13.10 \\
11.75-13.2\end{array}$ & $20-34$ & \\
\hline Belgium & $\begin{array}{l}18 / 11 / 94^{a} \\
18 / 11 / 94\end{array}$ & $\begin{array}{l}\text { Koksijde } \\
\text { Nieuwpoort }\end{array}$ & $\begin{array}{l}3 \\
1\end{array}$ & $\begin{array}{l}0^{\mathrm{b}} \\
0^{\mathrm{b}}\end{array}$ & $\begin{array}{c}14.4-15.4 \\
18.2\end{array}$ & $\begin{array}{l}22-28 \\
>29\end{array}$ & $\begin{array}{c}150-160 \\
150\end{array}$ \\
\hline
\end{tabular}

fitted with an eyepiece graticule. All the undamaged lower beaks found were measured, except in 2 cases when random sub-samples of Gonatus sp. beaks were measured (1000 beaks measured from 2351 and 981 beaks measured from 4549 respectively). In both cases the running mean of the measurements was plotted against the number of beaks measured and it was found to have stabilised at approximately 200 beaks (Fig. 2) so the sample measured is thought to be adequate. Mantle length (ML) and body weight of cephalopod prey were estimated from lower beak measurements, using regressions from Clarke (1986). For Haliphron atlanticus we had insufficient reference material to construct a regression relating LHL and body weight, and the size was therefore estimated based on comparison with the size of beaks of reference specimens. In Todarodes sagittatus, maturity can be

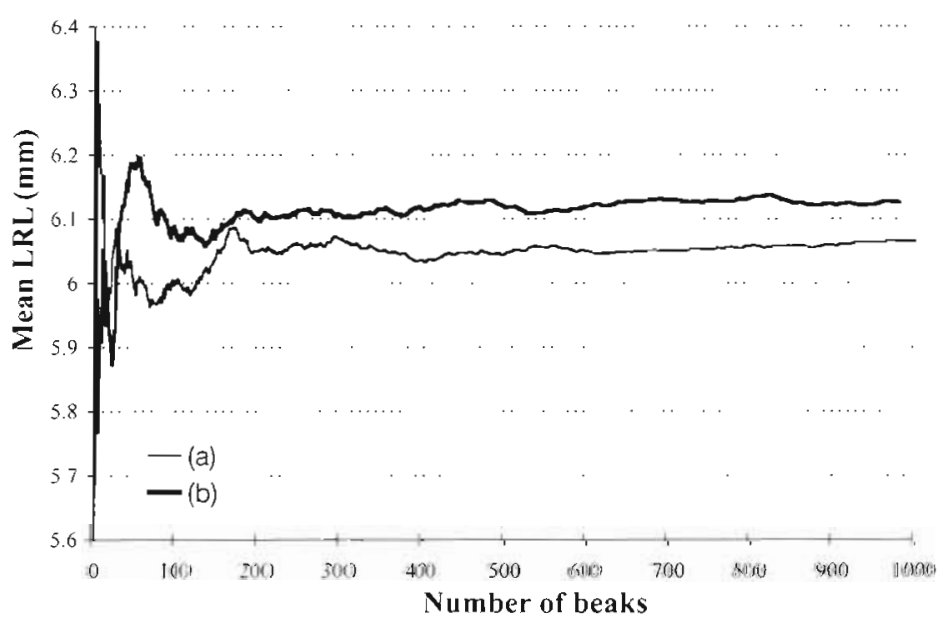

Fig. 2. Running mean of lower rostral length (LRL) of Gonatus sp. plotted against number of beaks measured for (a) Whale 3 from the Orkney mass stranding and (b) Whale 305 from the Cruden Bay mass stranding inferred from the lower beaks: those with pigmented wings correspond to maturing or mature squid (Hernández-García \& Piatkowski 1998). A single fish bone found in one stomach was identified by comparison with reference material and the original fish size was estimated using a regression derived from 15 specimens of that species in the reference collection

The total number of individuals of each cephalopod species present in a stomach was estimated as the number of lower or upper beaks (whichever was higher). The total weight represented by the beaks of each species in each stomach was estimated as (sum of weights represented by beaks measured)/(proportion of individuals measured).

Overall diet composition was calculated by summing the weights of all prey from each set of samples and expressing the weight of each species as a proportion of that total. Thus, each whale contributes to the overall diet in proportion to the total prey weight in its stomach.

Estimation of population food consumption. Data on diet were used to derive crude estimates of total cephalopod consumption by the population. Length estimates were obtained for 48 sperm whales stranded in the area over the period of this study (including the 42 whales in Table 1; additional data from Kompanje \& Reumer 1995, Lick et al. 1995, E. Rogan pers. comm.). These data were assumed to be representative of the North Atlantic 'population'. For each whale, body weight ( $W, \mathrm{~kg}$ ) was estimated from length $(L, m)$ using Lockyer's (1991) regression equation: $W=$ $0.0218 L^{2.74}$. Although derived from a small sample of whales (44) from the North Pacific and Antarctic, this remains the best available regression. 
Sergeant (1969) and Lockyer (1981) estimated the amount of food consumed by sperm whales to be 3 to $3.5 \%$ of their body weight per day. We used the median value of $3.25 \%$ of average body weight. Alternative calculations were based on Sigurjónsson \& Víkingsson's (1992) equation for daily energy requirements $\left(E, \mathrm{kcal} \mathrm{d}^{-1}\right): E=206.25 W^{0.783}$. Energy densities are not available for all the prey species (see Croxall \& Prince 1982, Clarke et al. 1985) but Gonatus spp. are recorded as having an energy density of $3.78 \mathrm{~kJ} \mathrm{~g}^{-1}$ (or $0.903 \mathrm{kcal} \mathrm{g}^{-1}$ ) by Clarke et al. (1985), and this value was used to convert estimated food requirements from energy to weight. We calculated $E$ for each of the 48 stranded whales for which weight had been estimated and took the average. This information on daily food consumption was also used to estimate the number of days of feeding represented by the beaks recovered from each stomach.

Estimates of sperm whale abundance in the eastern North Atlantic were taken from Christiansen et al. (1992) for Norwegian waters (5231) and Sigurjónsson \& Víkingsson (1992) for Icelandic waters (9645); both cases were based on results from sightings surveys in June-July 1989. We assume that these figures remain applicable for the period of our study.

Annual consumption of cephalopod prey $(C, t)$ was then estimated as

$$
C_{i}=N \times P_{i} \times F \times T
$$

where $i$ identifies the prey category, $N$ is the sperm whale population size, $P_{l}$ is the proportion by weight of prey category $i$ in the diet, for which we used pooled data from all the studied whales, $F$ is the average weight of food eaten daily per sperm whale (we used 2 different estimates as described above) and $T$ is the number of days whales spend in the feeding grounds. Initially we set $T$ at $120 \mathrm{~d}$, which corresponds to the summer feeding period assumed by Sigurjónsson \& Víkingsson (1992).

Since values of most of these parameters are provisional, we also explore the consequences of (1) a smaller population size, and (2) a shorter feeding period. We discuss the rationale for these modifications further below.

\section{RESULTS}

In all of the Scottish samples, food remains consisted almost entirely of cephalopod beaks (Table 2). A total of 6177 upper and 3846 lower beaks were recovered from the mass stranding on 7 December 1994; 1478 upper and 1171 lower beaks from the single stranding on 23 March 1995 and 6838 upper and 6501 lower beaks from the mass stranding on 28 January 1996. No

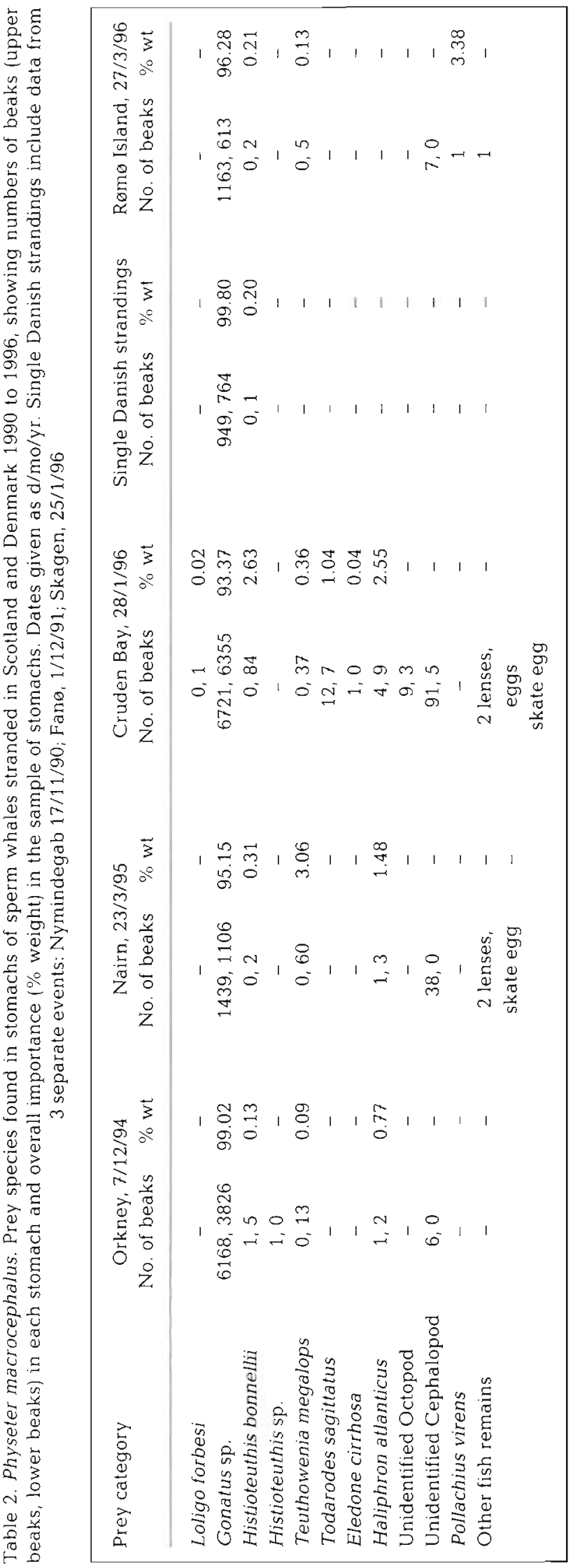


cephalopod flesh was found. Fish remains consisted of 1 skate egg capsule and 2 eye lenses in the single stranding in March 1995 and 1 skate egg capsule, 2 fish lenses and some fish eggs in the mass stranding of January 1996.

Four cephalopod species were identified from the mass stranding in December 1994 and the single stranding in April 1995 (Table 2): Gonatus sp. (probably $G$. fabricii based on its geographic distribution, Kristensen 1983, Bjørke 1995), Teuthowenia megalops, Histioteuthis bonnellii and the octopus Haliphron atlanticus. For the mass stranding in January 1996, the main prey was again Gonatus sp. (hereafter 'Gonatus'), and H. bonnellii, $T$. megalops, Todarodes sagittatus and the octopus $H$. atlanticus were also found. One whale had a lower beak of the squid Loligo forbesi and an upper beak of the octopus Eledone cirrhosa in its stomach. Another whale had a piece of net of approximately $100 \times 30 \mathrm{~cm}$ in the stomach. The $T$. sagittatus lower beaks ranged in size from 8.33 to $10.50 \mathrm{~mm}$ LRL and had pigmented wings and were probably therefore from maturing or mature whales.

The estimated ML of Gonatus from the mass stranding in December 1994 ranged from 155 to $295 \mathrm{~mm}$
( 4.67 to $8.00 \mathrm{~mm} \mathrm{LRL),} \mathrm{with} \mathrm{most} \mathrm{of} \mathrm{the} \mathrm{squid} \mathrm{being}$ between 195 and $245 \mathrm{~mm} \mathrm{ML}$ (5.50 and $6.72 \mathrm{~mm} \mathrm{LRL,}$ Fig. 3a). The Teuthowenia megalops ranged in size from 185 to $255 \mathrm{~mm} \mathrm{ML} \mathrm{(4.33} \mathrm{to} 5.98 \mathrm{~mm} \mathrm{LRL,} \mathrm{Fig.} \mathrm{3b).}$ From the single stranding in March 1995, estimated ML for Gonatus varied between 175 and $295 \mathrm{~mm}$ (5.00 to $8.00 \mathrm{~mm} \mathrm{LRL),} \mathrm{with} 2$ clear modes of 22.5 and $245 \mathrm{~mm}$ respectively ( 6.33 and $6.67 \mathrm{~mm}$ LRL) and those of T. megalops ranged from 145 to $275 \mathrm{~mm} \mathrm{ML} \mathrm{(3.24} \mathrm{to}$ $6.47 \mathrm{~mm} \mathrm{LRL)}$, with a single mode at $225 \mathrm{~mm}$ ML (5.23 mm LRL). Finally, from the mass stranding of January 1996, ML for Gonatus ranged from 145 to $295 \mathrm{~mm}$ (4.33 to $8.00 \mathrm{~mm}$ LRL), with most of the squid grouped between 225 and $245 \mathrm{~mm}$ (6.33 and $6.67 \mathrm{~mm} \mathrm{LRL}$ ), and

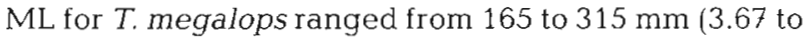
$7.50 \mathrm{~mm}$ LRL).

Food remains from the Danish samples also consisted almost entirely of cephalopod beaks (Table 2), the highest numbers being 1069 upper and 601 lower beaks from one of the whales in the mass stranding on 27 March 1996. No cephalopod flesh was found. A single fish bone (the post-temporal bone of a gadoid fish, probably a saithe Pollachius virens weighing approximately $15 \mathrm{~kg}$ ) and a fish eye lens, respectively, were
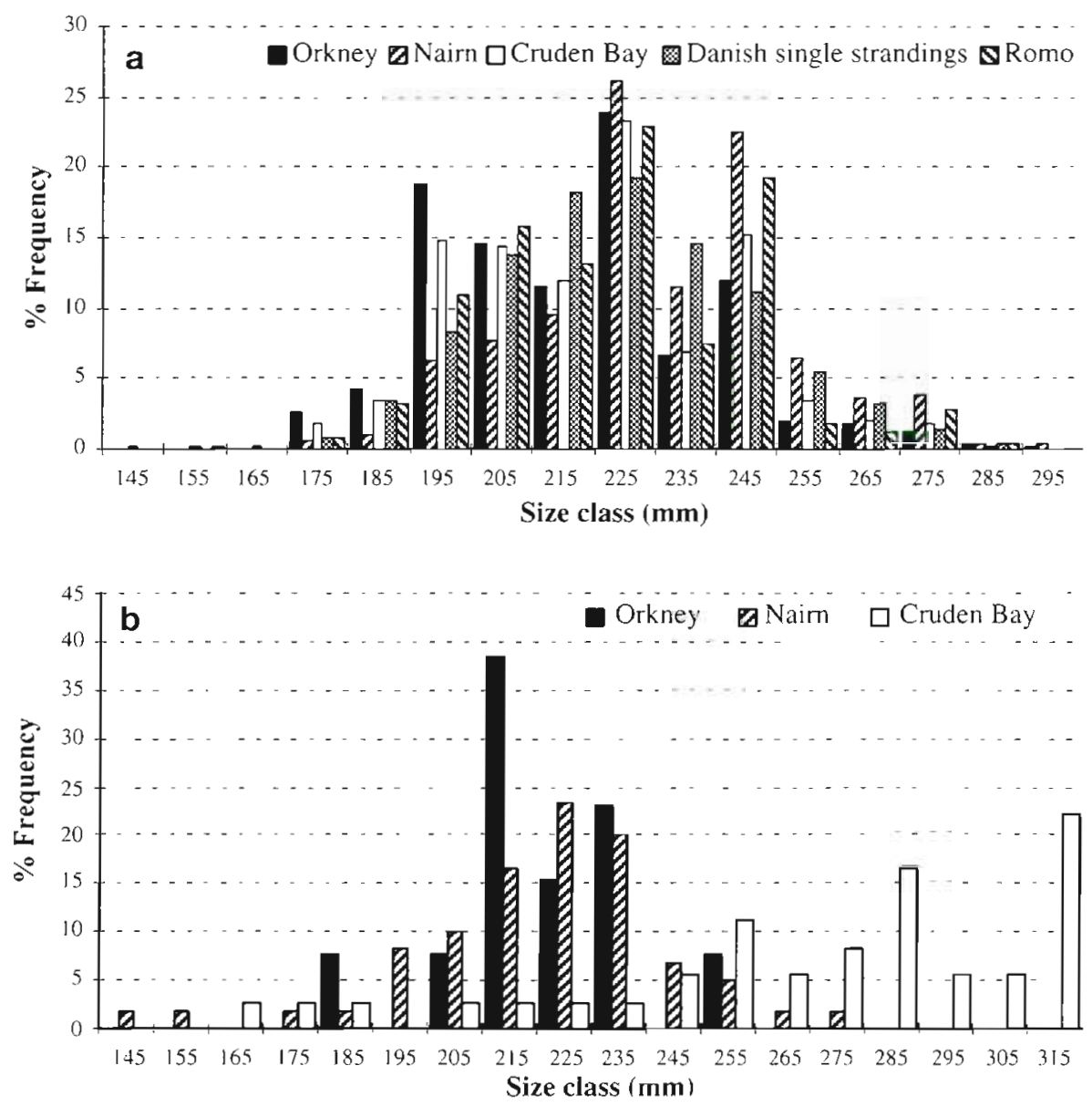

Fig. 3. Frequency distribution of estimated size (mantle length) of (a) Gonatus sp. and (b) Teuthowenia megalops in stomachs of sperm whales from the Orkney mass stranding, the sperm whale stranded in Nairn (Inverness), the Cruden Bay mass stranding, the single strandings in Denmark and the mass stranding in Romo (Denmark). Sample sizes for Gonatus sp. were $n_{\text {Orkney }}=6273$ beaks, $\mathrm{n}_{\mathrm{N}_{\text {alI I n }}}=1439, \mathrm{n}_{\text {Cruden Bdy }}=6744$, $\mathrm{n}_{\text {Danish sinqle strandings }}=949$, and $\mathrm{n}_{\text {Rema }}$ $=1162$. Sample sizes for $T$. mega lops were $\mathrm{n}_{\mathrm{Orknay}}=13$ beaks, $\mathrm{n}_{\text {vawm }}$ $=60$, and $n_{\text {Cruden Bay }}=37$ 
found in 2 whales from the mass stranding in March 1996.

Only Gonatus and Histioteuthis bonnellii were identified from the single strandings in Denmark (Table 2). In the mass stranding in March 1996, the main prey found was Gonatus. $H$, bonnellii and Teuthowenia megalops were also present.

Estimated ML of Gonatus from the single strandings ranged from 175 to $285 \mathrm{~mm}$ (5.00 to $7.74 \mathrm{~mm} \mathrm{LRL,} \mathrm{Fig.} \mathrm{3a).} \mathrm{Finally,}$ Gonatus size from the mass stranding in March 1996 ranged between 175 and $285 \mathrm{~mm}$ ML (5.00 and $7.74 \mathrm{~mm} \mathrm{LRL),}$ with a single mode at $245 \mathrm{~mm}(6.72 \mathrm{~mm}$ LRL).

The amount of food represented by prey remains recovered from the stomachs surpassed estimated daily food requirements in only 2 of the whales (Table 3). However, it was not possible to examine the whole gastric system and more material may have been present.

The mean estimated weight of the sperm whales from Scotland, Denmark and Belgium during the study period was $26.59( \pm 7.70) \mathrm{t}$. The estimated average weight of food required daily per sperm whale was $0.86 \mathrm{t}$. Using Sigurjónsson \& Víkingsson's (1992) equation, estimated daily requirements would be $2501797 \mathrm{~kJ} \mathrm{~d}^{-1}$ (597544 $\mathrm{kca} \mathrm{d}^{-1}$ ). Assuming that all prey had the same energy density as Gonatus (a reasonable approximation here since it made up at least $95 \%$ of the diet in all the strandings), this is equivalent to $0.66 \mathrm{t} \mathrm{d}^{-1}$.

Table 3. Physeter macrocephalus. Size, estimated daily food requirements (based on $3.25 \%$ of body weight) and stomach contents of stranded sperm whales. Final column shows the number of days feeding represented by beaks in the stomach

\begin{tabular}{|c|c|c|c|c|c|c|}
\hline Country & Whale & $\begin{array}{l}\text { Total } \\
\text { length } \\
(\mathrm{m})\end{array}$ & $\begin{array}{c}\text { Estimated } \\
\text { weight } \\
\text { (t) }\end{array}$ & $\begin{array}{l}\text { Daily food } \\
\text { requirements } \\
(\mathrm{kg})\end{array}$ & $\begin{array}{l}\text { Estimated } \\
\text { prey weight in } \\
\text { sample }(\mathrm{kg})\end{array}$ & $\begin{array}{l}\text { Food } \\
\text { present } \\
\text { (d) }\end{array}$ \\
\hline \multirow{10}{*}{ Scotland } & 3 & 12.80 & 23.6 & 825 & 924 & 1.21 \\
\hline & 6 & 13.40 & 26.7 & 935 & 384 & 0.44 \\
\hline & 9 & 12.80 & 23.6 & 825 & 4 & 0.00 \\
\hline & 11 & 12.50 & 22.1 & 773 & 79 & 0.11 \\
\hline & 1 & 13.70 & 28.4 & 993 & 392 & 0.43 \\
\hline & 302 & 12.85 & 23.8 & 834 & 18 & 0.02 \\
\hline & 303 & 12.10 & 20.2 & 707 & 61 & 0.09 \\
\hline & 304 & 13.75 & 28.7 & 1003 & 362 & 0.39 \\
\hline & 305 & 13.65 & 28.1 & 984 & 1103 & 1.21 \\
\hline & 306 & 13.65 & 28.1 & 984 & 97 & 0.11 \\
\hline \multirow[t]{7}{*}{ Denmark } & 421 & 11.85 & 19.1 & 668 & 61 & 0.10 \\
\hline & 422 & 11.73 & 18.6 & 649 & 1 & 0.00 \\
\hline & 423 & 13.10 & 25.1 & 879 & 162 & 0.20 \\
\hline & 401 & 12.80 & 23.6 & 825 & 15 & 0.02 \\
\hline & 405 & 12.95 & 24.3 & 851 & 25 & 0.03 \\
\hline & 408 & 11.90 & 19.3 & 675 & 0 & 0 \\
\hline & 412 & 12.15 & 20.4 & 715 & 248 & 0.37 \\
\hline
\end{tabular}

\section{DISCUSSION}

The present work represents the first large-scale study of sperm whale diet in the North Atlantic since the cessation of commercial whaling in the early 1980 s and demonstrates that squid, primarily Gonatus (probably $G$. fabricii), form a major part of the diet. Comparison of these results with the earlier work of Martin \& Clarke (1986), based on commercially caught whales, which indicated that cephalopods formed only $24 \%$ of the diet, raises some important questions: (1) Have sperm whale diets in the North Atlantic changed substantially over the last 2 decades? and (2) Do results from strandings provide a true picture of the diet?

The earliest studies on sperm whale diets in the Northeast Atlantic often 
Table 4. Physeter macrocephalus. Estimates of consumption of different prey species by sperm whale populations in the eastern North Atlantic ( $\mathrm{t}$ ). Calculations are based on the overall average diet for whales sampled in this study and 2 estimates of daily energy intake. Estimate A is based on the whales eating food equivalent to $3.25 \%$ of body weight daily, Estimate B is based on estimated energetic requirements and the calorific density of the main prey (see text). Figures were derived for Norwegian waters, Icelandic waters and both areas combined

\begin{tabular}{|c|c|c|c|c|c|c|c|}
\hline \multirow[t]{2}{*}{ Species } & \multirow[t]{2}{*}{$\%$ weight } & \multicolumn{2}{|c|}{$\begin{array}{l}\text { Norway } \\
\text { Estimate }\end{array}$} & \multicolumn{2}{|c|}{$\begin{array}{l}\text { Iceland } \\
\text { Estimate }\end{array}$} & \multicolumn{2}{|c|}{$\begin{array}{l}\text { Combined } \\
\text { Estimate }\end{array}$} \\
\hline & & A & B & A & B & A & B \\
\hline Haliphron atlanticus & 1.64 & 8896 & 6813 & 16403 & 12563 & 25300 & 19376 \\
\hline Eledone cirrhosa & 0.02 & 108 & 83 & 200 & 153 & 309 & 236 \\
\hline Gonatus sp. & 95.96 & 520545 & 398673 & 959788 & 735079 & 1480333 & 1133752 \\
\hline Histioteuthis bonnellii & 1.21 & 6564 & 5027 & 12102 & 9269 & 18666 & 14296 \\
\hline Loligo forbesi & 0.01 & 54 & 42 & 100 & 77 & 154 & 118 \\
\hline Teuthowenia megalops & 0.34 & 1844 & 1413 & 3401 & 2604 & 5245 & 4017 \\
\hline Todarodes sagittatus & 0.43 & 2333 & 1786 & 4301 & 3294 & 6633 & 5080 \\
\hline Pollachius virens & 0.39 & 2116 & 1.620 & 3901 & 2988 & 6016 & 4608 \\
\hline Total & 100.00 & 542460 & 415457 & 1000196 & 766026 & 1542656 & 1181484 \\
\hline
\end{tabular}

reported only general qualitative information on the prey. Haldane (1905) found a skate, cephalopod beaks, the jawbone of an anglerfish and the head of a shark in. the stomach of a sperm whale captured in 1904 off Shetland. Millais (1906) noted 'remains of predacious fish and cuttlefish beaks', and also fish hooks, in a sperm whale killed in 1904 off Shetland. Murray \& Hjort (1912) reported the presence of squid beaks and fish bones in the stomach of a sperm whale killed in 1903 off the east coast of Iceland. Hamilton (1914) examined the stomachs of 6 sperm whales captured in 1913 off the west coast of Ireland and found an almost complete specimen of Architeuthis in one whale and remains of fish in a second, while the remaining 4 whales had only cephalopod beaks in the stomachs.

The first of several more detailed studies was carried out by Roe (1969), who examined stomachs of 57 male sperm whales caught in July and August off Iceland. This author found demersal fish (lumpsucker Cyclopterus lumpus, redfish Sebastes sp. and monkfish Lophius piscatorius) to be the most important prey, as well as some cephalopods (later analysed by Clarke \& MacLeod 1976). The cephalopods found in these samples were (in order of importance by number) Histioteuthis bonnellii, an unidentified oegopsid, Haliphron atlanticus and Gonatus fabricii. Clarke \& MacLeod (1974) identified $H$. bonnellii and Taningia danae as the most numerous prey in the stomach of a male sperm whale captured off Vigo (NW Spain) in 1966. Martin \& Clarke (1986) analysed 221 stomach contents from sperm whales taken off Iceland between 1977 and 1981. Their results corroborated Roe's finding that fish was the most important prey (C. lumpus, Sebastes $\mathrm{sp}$. and $L$. piscatorius were again the most numerous species, along with cod Gadus morhua and various sharks). Squid of the families Histioteuthidae and
Cranchiidae were the most common cephalopod prey, and Todarodes sagittatus and G. fabricii were also found.

The most recent studies have all been based on strandings, González et al. (1994) found Mastigoteuthis sp., Teuthowenia megalops, Histioteuthis sp., Chiroteuthis sp. and Octopus vulgaris in the stomach of a juvenile sperm whale stranded in Galicia (NW Spain). Lick et al. (1995) recorded mainly Gonatus beaks along with small numbers of beaks of Haliphron atlanticus and Histioteuthis bonnellii in the stomach of a sperm whale stranded in Germany in November 1994. Clarke (1997) also recorded mostly Gonatus beaks in stomachs of 3 sperm whales stranded in Holland in the same month. In this case the only other species recorded was $H$. atlanticus. These 2 most recently published studies are thus in agreement with the results of the present study.

In clear contrast to the results from whales killed during whaling activities off Iceland (Roe 1967, Clarke \& MacLeod 1976, Martin \& Clarke 1986), very few fish remains were found in any of the stranded whales from the North Sea (González et al. 1994, Lick et al. 1995, Clarke 1997, this study). It is true that samples from strandings are usually incomplete, but this should not, in itself, necessarily result in any bias in evaluating diet composition.

The fact that no flesh was found in any of the samples in the present study seems to indicate that the whales had not been feeding immediately prior to stranding. Cephalopod beaks, which are relatively indigestible (except at the growing margins) and tend to become entrapped in the folds of the stomach lining, may accumulate until they are regurgitated, whereas fish remains could be retained for a shorter time in the stomach and/or digested more quickly. Bigg \& Fawcett 
(1985) record that squid beaks can remain in Northern fur seal stomachs $24 \mathrm{~h}$ longer than fish bones. Thus, the importance of cephalopods in the diet of stranded whales would tend to be overestimated. However, some fish remains can also spend a long time in predator stomachs and be retained in the folds (especially robust otoliths, Hernández-García 1995a). Eye lenses of both taxa should be equally likely to survive intact. Furthermore, squid flesh is digested faster than fish flesh (Bigg \& Fawcett 1985, Hernández-García 1995b). Interestingly, Martin \& Clarke (1986) acknowledge that they could have underestimated the importance of cephalopods, 'because squid crowns are small and thus possibly digested more quickly than the much larger entire fish'.

In the present study some trace fish remains were present, and the dominance of cephalopods is consistent with the findings of Lick et al. (1995) and Clarke (1997). However, we cannot rule out the possibility that larger quantities of fish had been eaten and their remains digested.

A serious challenge to the use of cephalopod beaks in stomach contents to interpret the diet of sperm whales was made by Clarke et al. (1988). These authors argued that the fleshy remains of the large squid Dosidicus gigas in the stomachs of sperm whales caught in the Southeast Pacific represented the main prey, whereas the beaks (mainly of other species) described from the same samples by Clarke et al. (1976) were ingested secondarily in the stomachs of D. gigas. Clarke et al. (1993) reply to this, pointing out that flesh of the small squids was also found, suggesting direct ingestion by the sperm whales. There have been similar arguments about whether grey seals Halichoerus grypus eat sandeels Ammodytidae. Prime \& Hammond's (1987) answer to this question is pertinent here: when sandeel otoliths were encountered in large numbers in faecal samples there were usually no other prey remains present and direct feeding on sandeels is the most likely interpretation. In faecal samples containing larger otoliths, a few sandeel otoliths were often also present and could represent secondary ingestion. In the present study there was no evidence at all of predation on larger squids and we believe that it is reasonable to assume that the beaks found are those of the prey of sperm whales. A possible additional bias is that smaller beaks may pass through the intestine, while larger beaks are retained in the stomach and subsequently regurgitated. In the present study most of the beaks found were of relatively similar sizes, although a few small beaks were found.

Aside from questions about differential digestion/ retention and secondary ingestion, information from strandings can be biased because sick or injured whales are more likely to be stranded than healthy individuals (Pierce \& Boyle 1991, Sekiguchi et al. 1992). In the context of the present study, there is some evidence of ill-health in sperm whales stranded in the North Sea, although it is not thought that this would have directly contributed to the stranding event. The only detailed pathological studies were those carried out on 4 whales stranded in Belgium in November 1994 and 3 whales stranded in The Netherlands in January 1995 (Jauniaux \& Coignoul 1996, Jauniaux et al. 1996, 1998), none of which had food remains in the stomach (Jauniaux pers. comm., Smeenk pers. comm.). Jauniaux and co-authors found that some of the whales were underweight and recorded the presence of various lesions. Levels of trace metals, organochlorine pesticides, their metabolites and chlorobiphenyl congeners in tissue samples from sperm whales stranded on North Sea coasts were generally within the range of values previously reported in the literature (Law et al. 1996, Bouquegneau et al. 1997, Joiris et al. 1997, McKenzie et al. 1997). However, high cadmium concentrations were found in the 4 Belgian sperm whales stranded in November 1994. One of the Orkney (1994) whales had a large part of its lower jaw missing. The wound had long since healed and the whale had a blubber thickness similar to that of other whales (R. J. Reid pers. obs.).

The sperm whale which stranded in the Firth of Forth in 1997 continued to swim up the Firth of Forth despite twice being grounded and efforts to persuade it to swim out of the Firth. It may be suggested that the whales are aware of the direction in which they need to travel, but have difficulty navigating once they enter the unfamiliar and shallow waters of the North Sea. Smeenk (1997) has commented that the North Sea may be regarded as a 'sperm whale trap'

The main prey found in the 17 sperm whale stomachs containing food remains was the oceanic squid Gonatus [probably G. fabricil (Lichtenstein), given its distribution (Kristensen 1983)]. G. fabricii is an oceanic species considered to be the most abundant squid in the Arctic and Sub-arctic area of the North Atlantic (Kristensen 1983). Juveniles (ML $\leq 50 \mathrm{~mm}$ ) are caught in the surface layers but, at a length of 50 to $70 \mathrm{~mm}, G$. fabricii disappears from the surface, probably moving to deeper waters (Bjørke 1995). Squids of 80 to $250 \mathrm{~mm}$ ML have been caught at depths of 200 to $550 \mathrm{~m}$ with deep pelagic and bottom trawls (Wiborg et al. 1982, 1984). Off West Greenland, males are thought to mature at a ML of about $200 \mathrm{~mm}$ (probably aged $2 \mathrm{yr}$ ), with females maturing at a ML larger than $200 \mathrm{~mm}$ (aged 2 to $3 \mathrm{yr}$ ) (Kristensen 1983). The ML estimated for the majority of Gonatus in the sperm whale stomachs varied between 205 and $245 \mathrm{~mm}$ (Fig. 3a), which corresponds with the size of mature squid (Wiborg et al. 1982, Kristensen 1983). 
The main spawning period for Gonatus fabricii in the Norwegian Sea is from December to April (Bjorke 1995). However, very few mature specimens or egg masses have ever been found (the first record of putative egg masses, taken in a pelagic trawl, is in Bjorke et al. 1997), which led Kristensen (1984) to suggest that spawning probably takes place at depths greater than $200 \mathrm{~m}$. Areas of spawning have not been definitely identified but Wiborg (1979) considers that they may coincide with localities where bottlenose whales Hyperoodon ampullatus Forster were abundant (off Møre and Vesterålen, west of Svalbard and between Iceland and Jan Mayen, Fig. 1). This is supported by the finding of squid spermatophores in the stomach of a bottlenose whale which had fed exclusively on $G$. fabricii (as indicated by beaks representing more than 1 t of squid) (Lick \& Piatkowski 1998).

Moiseev (1991) collected data on the vertical distribution of Gonatus fabricii using manned underwater vehicles. He observed squid along the North-Atlantic Ridge (at $49^{\circ}$ and $59^{\circ} \mathrm{N}$ and in the Sea of Irminger) from July to September 1986. During the day, squid were found between 420 and $1200 \mathrm{~m}$ depth, while at night they occurred at depths from 350 to $1200 \mathrm{~m}$. He concluded that, because of the considerable overlap in distribution between day at night, the daily vertical migration of $G$. fabricii was probably insignificant.

The high number of Gonatus beaks found in stomachs, and the fact that most of them were from large squid, suggests the possibility that the sperm whales had been feeding on shoals of adult squid. Akimushkin (1955) suggested that, because squid beaks of each species in the food of sperm whales tended to be of similar size, this was an indication of squids living in shoals of individuals of similar age. Gaskin \& Cawthorn (1967) also noted the regularity in the sizes of beaks recovered from stomachs of sperm whales caught in New Zealand.

Most squid species aggregate in dense concentrations to mate and lay eggs (e.g. Hanlon \& Messenger 1996). Females typically die after spawning and, in some cases, so do the males, although it is believed that male Gonatus could survive to breed again (Kristensen 1984). Clarke (1980) pointed out that if the whales were feeding on spawning aggregations, they would be eating dense concentrations of incapacitated and dying squids at their maximum size. The timing of the strandings (between the end of December to March) broadly coincides with the spawning period for Gonatus (December to April). If the sperm whales were feeding on spawning aggregations, it would explain the high numbers and uniform sizes of beaks found in some of the stomachs.

The majority of the other cephalopod remains found in the stomachs were also from oceanic species. Of the
3 other oceanic squids eaten, Todarodes sagittatus is the best-known, having been the object of a directed fishery in several northern countries, most importantly in Norway (Sundet 1985, Borges \& Wallace 1993). All 3 species are widely distributed in the Atlantic, extending into Arctic waters, and are reported from a wide range of water depths (Voss 1969, Kristensen 1980, Nixon 1983, Voss 1985, Guerra 1992). The biology of Histioteuthis bonnelli is relatively poorly known. However, there is information on size at maturity in $T$. sagittatus and T. megalops (Nixon 1983, Wiborg \& Beck 1984), and both species are known to undertake daily vertical migrations (Lu \& Clarke 1975, Hanlon \& Messenger 1996), although the latter comes to the surface by day rather than at night. The size of the $T$. megalops eaten by sperm whales in the present study (145 to $315 \mathrm{~mm} \mathrm{ML)} \mathrm{spans} \mathrm{the} \mathrm{previously} \mathrm{reported} \mathrm{size} \mathrm{ranges}$ for juveniles ( 70 to $180 \mathrm{~mm}$ ) and adults $(260$ to $352 \mathrm{~mm}$ ). T. sagittatus shows a marked sexual dimorphism in body size as well as a wide range of size at maturity. The size and pigmentation of the lower beaks found in the sperm whale stomachs were consistent with mature or maturing squid.

The octopus Haliphron atlanticus is a cosmopolitan bottom-living species recorded from depths up to 3180 m (Clarke \& Lu 1975, Guerra 1992). However, Collins et al. (1995) reported an immature female (estimated weight $11.5 \mathrm{~kg}$ ) captured by a bottom trawler in Shetland at a depth of around $180 \mathrm{~m}$. Based on a comparison of beak sizes, the octopuses taken by the sperm whales were all smaller than those recorded by Collins et al. (1995).

The other cephalopod prey found (Loligo forbesi and Eledone cirrhosa) are both mainly coastal species, although they are also caught offshore (e.g. at Rockall, off Scotland, Pierce et al. 1994). Only 1 beak of each species was found, in samples from Cruden Bay (Scotland) in 1994. The presence of these beaks, along with 2 skate egg capsules among the food remains in samples from Scotland and the saithe bone recorded from Denmark, provides the only tentative evidence of feeding in coastal waters.

Of the 25 sperm whales stranded in the North Sea area for which stomach contents were examined, food remains were found only in the Scottish and Danish whales, with the largest amount of remains being present in stomachs from Scotland. No prey remains were found in the whales stranded in Belgium in 1994, although 2000 beaks were found in a whale stranded in The Netherlands in 1994 (Clarke 1997). The sperm whale that stranded in the Firth of Forth in 1997 also had an empty stomach. It had spent at least $11 \mathrm{~d}$ in the Firth of Forth (R. J. Reid pers, obs.) and no food remains were found in the stomach. 
From the evidence available, it appears that the sperm whales were feeding in deep waters of $f$ Norway on spawning concentrations of oceanic squids. After entry into the North Sea, little further feeding took place. An obvious inference is that sperm whales do not enter the North Sea to feed: they may normally feed little while in transit or the food available in the North Sea may be unsuitable.

Although large numbers of beaks were found in some of the stomachs, at most they represented little more than a single day's food requirements (Table 3 ). Of course, it was never certain that the entire stomach contents were recovered. Clarke (1980) estimated that an average female sperm whale would retain beaks in the stomach for 2.1 to $2.5 \mathrm{~d}$ while the average male would retain them for 1.2 to $1.6 \mathrm{~d}$. Beaks are probably then regurgitated.

Estimates of daily food requirements differ depending on which source is used: Sergeant (1969), Lockyer (1981) or Sigurjónsson \& Víkingsson (1992). The latter estimate is expressed as energy rather than weight, requiring an explicit assumption to be made about the calorific density of the prey. The value we used, for Gonatus, derives from Clarke et al. (1985). The family Gonatidae is characterised by the presence of large amounts of low density oil in the liver, which allows the squids to be neutrally buoyant (Clarke et al. 1979). The values given by Clarke et al. (1985) refer to juveniles and the authors acknowledge that, in mature specimens, the presence of oil would increase the calorific value. This would lead to reductions in our estimates of the total weight of squid consumed.

Our crude calculations indicate that sperm whales in the eastern North Atlantic could take up to 1.5 million $t$ of squid during the feeding season, mostly Gonatus fabricii. This obviously involves a series of assumptions, the first of which is that the stomach contents were representative. We have already noted that studies on whales caught off Iceland indicated predation on fish as well as cephalopods. Although most recent studies agree that cephalopods are the main prey, they have been based on stranded whales. If the whales in the present study had eaten fish and cephalopods in the proportions suggested by Martin \& Clarke (1986), i.e. $24 \%$ of the diet being cephalopods, the estimate of consumption of Gonatus would come down to $370000 \mathrm{t}$ at most. Furthermore, Gonatus might be taken only during the spawning period, and only by whales in the spawning area. Hence the number of days of feeding and the population size assumed might both have been unrealistically large.

We have also implicitly assumed that the whales stranded in the North Sea were of the same average size as the population as a whole and that daily feeding rate is constant. In fact, if the whales are building up energy reserves for breeding, feeding rates may be considerably higher during the period spent in northern waters.

The total sperm whale population in the North Atlantic is presently unknown, hence we used estimates by Christensen et al. (1992) and Sigurjónsson \& Víkingsson (1992) based on a survey in 1989. The time period over which these whales remain in northern waters is also uncertain. Sightings and strandings of sperm whales occur all year round, suggesting that at least some whales remain in the area during the winter months (Christensen et al. 1992, Smeenk 1997). Whitehead \& Arnbom (1987), working on sperm whales off Galapagos, suggested that mature male sperm whales do not breed every year but, because of energetic or other limitations, remain in the cold water areas where they feed.

The only previous estimate for the amount of cephalopods eaten by sperm whales for this area (Sigurjónsson \& Víkingsson 1992) used dietary data from Martin \& Clarke (1986). The resulting figure, approximately 33000 to $40000 \mathrm{t}$ of cephalopods eaten per year in Icelandic waters (north of $60^{\circ} \mathrm{N}$ ), is not directly comparable to our estimate since we considered all whales in the eastern North Atlantic (north of $50^{\circ} \mathrm{N}$ (i.e. a total population of 14876 whales rather than 2456 whales, based on their figures). Scaling up their figures would give a maximum estimate of around $242000 \mathrm{t}$ of cephalopods eaten, and much of the remaining difference is then attributable to the differing estimates of dietary importance for cephalopods.

Of the species eaten by sperm whales in the Northeast Atlantic, only Todarodes sagittatus has been the object of a significant directed fishery, mainly in Norway (Sundet 1985). The main prey species, Gonatus fabricii, although thought to be very abundant, has never been the object of a directed fishery. Juvenile squid stranded in autumn on the Norwegian coast are used as bait (Wiborg et al. 1982) and there is also a substantial by-catch in shrimp trawls off West Greenland (Piatkowski \& Wieland 1993). It has been proposed as a possible fishery resource (Wiborg 1979. Wiborg et al. 1982, 1984, Piatkowski \& Wieland 1993) but fishing experiments with pelagic trawls have been unsuccessful, due to the lack of knowledge on the location of adults and spawning aggregations (Wiborg et al. 1982). Bjørke (1995) estimated the stock of juvenile Gonatus in the Norwegian Sea in July 1994 as 2 to 3 million t. He noted that this could be an underestimate due to inefficiency of the gear. Gonatus is eaten by a variety of predators including the bottlenose whale, narwhal Monodon monoceros, beluga Delphinapterus leucas, Sowerby's beaked whale Mesoplodon bidens, pilot whale Globicephala melas, Northern fur 
seal Callorhinus ursinus, hooded seal Cystophora cristata, harp seals Phoca groenlandica, herring Clupea harengus, salmon Salmo salar, blue ling Molva byrkelange, Greenland halibut Reinhardtius hippoglossoides, cod Gadus morhua, rat-tails Coryphaenoides spp., and redfish Sebastes marinus (Murray \& Hjort 1912, Hjort \& Ruud 1929, Grimpe 1933, Nesis 1965, Benjaminsen \& Christensen 1979, Wiborg 1979, Clarke \& Kristensen 1980, Lear 1980, Wiborg et al. 1982, 1984, Kristensen 1983, Lydersen et al. 1991, Bjørke 1995, Martin \& Christiansen 1997, Lick \& Piatkowski 1998). If sperm whales take as much as 1.5 million $t$ of Gonatus annually from the North Atlantic, then it is likely that Bjørke's estimate of Gonatus abundance is a very conservative one. If, in the future, Gonatus becomes a fishery resource, the effect on the sperm whale population would need to be carefully monitored.

Acknowledgements. M.B.S. was supported by the CEC (Contract ERB 4001 GT93 3630). R.J.R., H.M.R. and I.A.P.P. were funded by the UK Department of the Environment. Martin Collins, Toby Carter and Steve Hoskins assisted with collection of samples in Scotland. Gerard Wijnsma assisted with measuring beaks. Jianjun Wang supplied the map used in Fig. 1. Chris Smeenk, Dave Raffaelli and 4 anonymous referees made helpful comments on the manuscript.

\section{LITERATURE CITED}

Akimushkin II (1955) Okharaktere pitaniya kashalota (On the Nature of sperm whale feeding). Dokl Akad Nauk SSSR 101:1139-1140

Beale T (1839) The natural history of the sperm whale..., to which is added a sketch of a south-sea whaling voyage, in which the author was personally engaged. Van Voorst, London

Benjaminsen T, Christensen I (1979) The natural history of the bottlenose whale, Hyperoodon ampullatus (Forster). In: Winn HE, Olla BL (eds) Behavior of marine animals, Vol 3. Plenum Press, New York, p 143-164

Bennett $F(1840)$ Narrative of a whaling voyage round the globe, from the year 1833 to 1836 . R Bentley, London

Berrow SD, Rogan E (1997) Review of cetaceans stranded on the Irish coast, 1901-95. Mammal Rev 27:51-76

Berzin A.A (1971) Kashalot (The sperm whale). Izdat Pischevaya Promyshlennost Moscow. (English Translation., 1972, Israel Program for Scientific Translations, Jerusalem)

Best PB (1979) Social organization in sperm whales, Physeter macrocephalus. In: Winn HE, Olla BL (eds) Behavior of marine animals, Vol 3. Plenum Press, New York, p 227-289

Betesheva EI (1960) Pitanie kashalota (Physeter catodon L.) i Berardiusy (Berardius bairdi Stejneger) v raiona Kuril'skoi gryady (Feeding of the sperm whale [Physeter catodon L.] and the beaked whale [Berardius bairdi Stejneger] in the Kuril Islands area). Tr Vses Gidrobiol O-va 10:227-234

Betesheva EI (1961) Pitanie promyslovykh kitov Prikuril'skogo raiona (Food of commercial whales in the Kuril region). Tr Inst Morfol Zhivotn Akad Nauk SSSR 34:7-32

Bigg MA, Fawcett I (1985) Two biases in diet determination of northern fur seals (Callorhinus ursinus). In: Beddington JR, Beverton RJH, Lavigne DM (eds) Marine mammals and fisheries. George Allen \& Unwin, London, p 284-291
Bjørke H (1995) Norwegian investigations on Gonatus fabricii (Lichtenstein). ICES CM 1995/K:12

Bjorke H, Hansen K, Sundet RC (1997) Egg masses of the squid Gonatus fabricii (Cephalopoda, Gonatidae) caught with pelagic trawl off northern Norway. Sarsia 82:149-152

Borges TC. Wallace JC (1993) Some aspects of the fishery biology of the ommastrephid squid Todarodes sagittatus (Lamarck, 1798) from the Northeast Atlantic. In: Okutani $\mathrm{I}$, O'Dor RK, Kubodera $\mathrm{T}$ (eds) Recent advances in cephalopod fisheries biology. Tokai University Press, Tokyo, p 25-36

Bouquegneau JM, Debacker V, Gobert S, Nellissen JP (1997) Toxicological investigations on four sperm whales stranded on the Belgian coast: inorganic contaminants Bull Inst R Sci Nat Belg Biologie 67(Suppl):75-78

Buchanan JY (1896) The sperm whale and its food. Nature 53 $223-225$

Christensen I, Haug T, Øien N (1992) Seasonal distribution, exploitation and present abundance of stocks of large baleen whales (Mysteceti) and sperm whales (Physeter macrocephalus) in Norwegian and adjacent waters. ICES J Mar Sci 49:341-355

Clarke A, Clarke MR, Holmes LJ, Waters TD (1985) Calorific values and elemental analysis of eleven species of oceanic squids (Mollusca: Cephalopoda). J Mar Biol Assoc UK 65 $983-986$

Clarke MR (1976) Observation on sperm whale diving. J Mar Biol Assoc UK 56:809-810

Clarke MR (1980) Cephalopoda in the diet of sperm whales of the southern hemisphere and their bearing on sperm whale biology. Discovery Rep 37:1-324

Clarke MR (ed) (1986) A handbook for the identification of cephalopod beaks. Clarendon Press, Oxford

Clarke MR (1997) Cephalopods in the stomach of a sperm whale stranded between the islands of Terschelling and Ameland, southern North Sea. Bull Inst R Sci Nat Belg Biologie 67(Suppl):53-55

Clarke MR, Kristensen TR (1980) Cephalopod beaks from the stomachs of two northern bottlenosed whales (Hyperoodon ampullatus). J Mar Biol Assoc UK 60:151-156

Clarke MR, Lu CC (1975) Vertical distribution of cephalopods at $18^{\circ} \mathrm{N} 25^{\circ} \mathrm{W}$ in the North Atlantic. J Mar Biol Assoc UK 55:165-182

Clarke MR, MacLeod N (1974) Cephalopod remains from a sperm whale caught off Vigo, Spain. J Mar Biol Assoc UK 54:959-968

Clarke MR, MacLeod N (1976) Cephalopod remains from sperm whales caught off Iceland. J Mar Biol Assoc UK 56: $733-749$

Clarke MR, Pascoe PL (1997) Cephalopod species in the diet of a sperm whale (Physeter catodon) stranded at Penzance, Cornwall. J Mar Biol Assoc UK 77:1255-1258

Clarke MR, Macleod N, Paliza O (1976) Cephalopod remains in the stomachs of sperm whales caught off Peru and Chile. J Zool Lond 180:477-493

Clarke MR, Denton EJ, Gilpin-Brown JB (1979) On the use of ammonium for buoyancy in squids. J Mar Biol Assoc UK 59:259-279

Clarke MR, Macleod N, Castello HP, Pinedo MC (1980) Cephalopod remains from the stomach of a Sperm whale stranded at Rio Grande do Sul in. Brazil. Mar Biol 59: $235-239$

Clarke MR, Martins HR, Pascoe P (1993) The diet of sperm whales (Physeter macrocephalus Linnaeus 1758) off the Azores. Phil Trans R Soc Lond B 339:67-82

Clarke R (1956) A giant squid swallowed by a sperm whale Proc Zool Soc Lond 126:645 
Clarke R, Paliza O, Aguayo A (1988) Sperm whales of the Southeast Pacific. Part IV: Fatness and feeding. Invest Cetacea 21:54-195

Collins MA, Brown EG, Pierce GJ (1995) The octopus Haliphron atlanticus Steenstrup caught in Shetland waters. Shetl Nat 1:123-124

Croxall JP, Prince PA (1982) Calorific content of squid (Mollusca: Cephalopoda). BAS Bull 55:27-31

Dong $Z$. (1984) The food and feeding habits of the sperm whale (Physeter catodon Linnaeus). J Fish China 8: 327-332, (in Chinese with English abstract)

Evans PGH, Scanlan G (1989) Historical review of cetaceans in British and Irish waters. Greenpeace Environmental Trust, London

Fraser FC (1974) Report on Cetacea stranded on the British coasts from 1948 to 1966. British Museum (Natural History), No. 14, London

Gambell R (1976) World whale stocks. Mammal Rev 6:41-53

Gaskin DE, Cawthorn MW (1967) Squid mandibles from the stomachs of sperm whales (Physeter catodon L.) captured in the Cook Strait region of New Zealand. NZ J Mar Freshw Res 1:59-70

González AF, López A, Guerra A, Barreiro A (1994) Diets of marine mammals stranded on the northwestern Spanish Atlantic coast with special reference to Cephalopoda. Fish Res 21:179-191

Gosho ME, Rice DW, Breiwick JM (1984) The sperm whale, Physeter macrocephalus. Mar Fish Rev 46:54-64

Grimpe G (1933) Die Cephalopoden des arktischen Gebietes. Fauna Arctica 6:489-514

Guerra A (1992) Mollusca, Cephalopoda. In: Ramos Sánchez MA, Alba Tercedor J, Bellés i Ross X, Gosálbez i Nogueira J, Guerra Sierra A, Macpherson Mayol E, Martín Piera F, Serrano Marino J, Templado González J (eds) Fauna Ibérica, Vol 1. Museo Nacional de Ciencias Naturales, CSIC, Madrid

Gunnlaugsson T, Sigurjónsson J (1990) NASS-87: estimation of whale abundance based on observations made onboard Icelandic and Faroese survey vessels. Rep Int Whal Comm 40:571-580

Haldane RC (1905) Notes on whaling in Shetland, 1904. Ann Scot Nat Hist 54:65-72

Hamilton JE (1914) Belmullet whaling station. Rep Brit Assoc Advmt Sci 1914:125-161

Hanlon RT, Messenger JB (1996) Cephalopod behaviour. Cambridge University Press, Cambridge

Harmer SF (1917) Report on Cetacea stranded on the British coasts during 1916. British Museum (Natural History), No. 4, London

Heezen BC (1957) Whales entangled in deep sea cables. Deep-Sea Res 4:105-115

Hernández-García V (1995a) The diet of the swordfish Xiphias gladius Linnaeus, 1758, in the central east Atlantic with an emphasis on the role of cephalopods. Fish Bull 93:403-411

Hernández-García V (1995b) Cephalopods from the CECAF area: fishery and ecology role. ICES CM 1995/K:18

Hernández-García V, Piatkowski U (1998) Development of the darkening of the Todarodes sagittatus beaks and its relation to growth and reproduction. S Afr J Mar Sci 20: $363-373$

Hjort J, Ruud JT (1929) Whaling and fishing in the North Atlantic. Rapp P-V Reun Cons Perm Int Explor Mer 56: $5-123$

Jauniaux T, Coignoul F (1996) Hard palate and skin ulcers of sperm whales (Physeter macrocephalus) stranded along the Belgian and Dutch coasts during 1994-95. Eur Res Cetaceans 10:268
Jauniaux $T$, Brosens L, Jacquinet, E, Lambrigts, D, Addink, M, Coignoul $F(1996)$ Lesions observed on sperm whales (Physeter macrocephalus) stranded along the Belgian and Dutch coasts during winter 1994-95. Eur Res Cetaceans 10:272- 275

Jauniaux I, Brosens L, Jacquinet E, Lambrigts D, Addink M, Smeenk C, Coignoul F (1998) Postmortem investigations on winter stranded sperm whales from the coasts of Belgium and the Netherlands. J Wild Dis 34:99-109

Joiris CR, Holsbeek L, Bossicart M, Tapia G (1997) Mercury and organochlorines in four sperm whales stranded on the Belgian coast, November 1994. Bull Inst R Sci Natur Belg, Biologie 67(Suppl):69-73

Kawakami T (1980) A review of sperm whale food. Sci Rep Whales Res Inst 32:199-218

Kompanje EJO, Reumer JWF (1995) Strandings of male sperm whales Physeter macrocephaius Linnaeus, 1758 in Western Europe between October 1994 and January 1995. Deinsea 2:89-94

Kristensen TK (1980) Large mature female of Histioteuthis bonnellii (Ferussac, 1835) (Mollusca: Cephalopoda) recorded from the Davis Strait, West Greenland. Steenstrupia $6: 73-79$

Kristensen TK (1983) Gonatus fabricii. In: Boyle PR (ed) Cephalopod life cycles, Vol 1, Species accounts. Academic Press, London, p 159-174

Kristensen TK (1984) Biology of the squid Gonatus fabrici (Lichtenstein, 1818) from West Greenland waters. Medd Gronl 13:3-20

Law RJ, Stringer RL, Allchin CR, Jones BR (1996) Metals and organochlorines in sperm whales (Physeter macrocephalus) stranded around the North Sea during the 1994/1995 winter. Mar Pollut Bull 32:72-77

Lear WH (1980) Food of the Atlantic salmon in West Greenland-Labrador Sea area. Rapp P-V Réun Cons Int Explor Mer 176:55-59

Lick R, Piatkowski U (1998) Stomach contents of a northern bottlenose whale (Hyperoodon ampullatus) stranded at Hiddensee, Baltic Sea. J Mar Biol Assoc UK 78:643-650

Lick R, Bandomir-Krischak B, Stede M, Wulf J, Benke H (1995) Case report of two large whales (Megaptera novaeangliae and Physeter macrocephalus) in the German part of the North Sea. Eur Res Cetaceans 9:162-163

Lockyer C (1981) Estimates of growth and energy budget for the sperm whale, Physeter catodon. FAO Fish Ser No. 5(3): 489-504

Lockyer C (1991) Body composition of the sperm whale, Physeter catodon, with special reference to the possible function of fat deposits. Rit Fiskideildar 12:1-24

Lu CC, Clarke MR (1975) Vertical distribution of cephalopods at $40^{\circ} \mathrm{N}, 53^{\circ} \mathrm{N}$ and $60^{\circ} \mathrm{N}$ at $20^{\circ} \mathrm{W}$ in the North Atlantic. J Mar Biol Assoc UK 55:143-163

Lydersen C, Angantyr LA, Wiig Ø, Øritsland $\Upsilon$ (1991) Feeding habits of Northeast Atlantic harp seals (Phoca groenlandica) along the summer ice edge of the Barents Sea. Can J Fish Aquat Sci 48:2181-2183

Martin AR, Clarke MR (1986) The diet of sperm whales (Physeter macrocephalus) captured between Iceland and Greenland. J Mar Biol Assoc UK 66:779-790

Martin B, Christiansen B (1997) Diets and standing stocks of benthopelagic fishes at two bathymetrically different midoceanic localities in the northeast Atlantic. Deep-Sea Res 44:541-558

Matthews LH (1938) The sperm whale, Physeter catodon. DisCovery Rep 17:93-168

McKenzie C. Reid RJ, Wells DE (1997) Organic contaminants and trace metals in sperm whales (Physeter macroceph- 
alus) stranded in Northern European waters 1993-1996. Scottish Fisheries Working Paper, Fisheries Research Services Marine Laboratory, Aberdeen

Mikhalev JA, Savusin VP, Kishiyan NA (1981) To the problem of the feeding of sperm whales from the Southern Hemisphere. Rep Int Whal Comm 31:737-745

Millais JG (1906) Mammals of Great Britain and Ireland Longmans Green, London

Mizue K (1951) Food of whales (in the adjacent waters of Japan). Sci Rep Whales Res Inst Tokyo 5:81-90

Moiseev SI (1991) Observation of the vertical distribution and behaviour of necktonic squids using manned submersibles. Bull Mar Sci 49:446-456

Murray J, Hjort J (1912) The depths of the ocean. Macmillan \& Co, London

Nesis KN (1965) Distribution and feeding of young squids Gonatus fabricii (Licht.) in the Labrador Sea and the Norwegian Sea. Oceanology 5:102-108

Nixon M (1983) Teuthowenia megalops. In: Bpyle PR (ed) Cephalopod life cycles, Vol 1, Species accounts. Academic Press, London, p 233-250

Norris KS, Harvey GW (1972) A theory for the function of the spermaceti organ of the sperm whale (Physeter catodon L.). NASA Spec Publ 262:397-417

Okutani T, Nemoto T (1964) Squid as the food of sperm whales in the Bering Sea and Gulf of Alaska. Sci Rep Whales Res Inst Tokyo 18:111-122

Ostrom PH, Lien J, Macko SA (1993) Evaluation of the diet of Sowerby's beaked whale, Mesoplodon bidens, based on isotopic comparisons among north-western Atlantic cetaceans. Can J Zool 71:858-861

Pascoe PL, Mickiewicz MC, Castelio HP (1990) Cephalopod remains from the stomach of a sperm whale stranded off Patagonia. Mar Biol 104:1-4

Papastavrou V, Smith SC, Whitehead H (1989) Diving behaviour of the sperm whale Physeter macrocephalus off the Galapagos Islands. Can J Zool 67:839-846

Pérez-Gándaras G (1986) Estudios sobre los cefalópodos ibéricos: sistemática y bionomía mediante el estudio morfométrico comparado de sus mandíbulas. PhD thesis, Universidad Complutense de Madrid

Piatkowski U, Wieland K (1993) The boreoatlantic gonate squid Gonatus fabricii: distribution and size off West Greenland in summer 1989 and in summer and autumn 1990. Aquat Living Resour 6:109-114

Pierce GJ, Boyle PR (1991) A review of methods for diet analysis in piscivorous marine mammals. Oceanogr Mar Biol Annu Rev 29:409-486

Pierce GJ, Boyle PR, Hastie LC, Shanks A (1994) Distribution and abundance of the fished population of Loligo forbesi in UK waters: analysis of fishery data. Fish Res 21:193-216

Prime $\mathrm{JH}$, Hammond PS (1987)"Quantitative analysis of gray seal diet from fecal analysis. In: Huntley $A C$, Costa DP, Worthy GAJ, Castellini MA (eds) Approaches to marine mammal energetics. Soc Mar Mammalogy Spec Publ 1. Lawrence, Kansas, p 165-181

Rice DW (1978) Sperm whales. In: Haley D (ed) Marine mammals of Eastern North Pacific and Arctic waters. Pacific Search Press. Seattle, $p$ 82-87

Rice DW (1989). Sperm whale Physeter macrocephalus Linnaeus, 1758. In: Ridgway SH, Harrison RJ (eds) Handbook of marine mammals, Vol 4. Academic Press, London, p $177-233$

Roe HSJ (1969) The food and feeding habits of the sperm whales (Physeter catodon L.) taken off the West coast of Iceland. J Cons Int Explor Mer 33:93-102
Sekiguchi K, Klages NTW, Best PB (1992) Comparative analysis of the diets of smaller odontocete cetaceans along the coast of Southern Africa. S Afr J Mar Sci 12:843-861

Sergeant DE (1969) Feeding rates of cetacea. Fiskeridir Skr Ser Havunders 15:246-258

Sigurjónsson J, Vikingsson GA (1992) Investigations on the ecological role of cetaceans in Icelandic and adjacent waters. ICES CM 1992/N:24

Smeenk C (1997) Strandings of sperm whales Physeter macrocephalus in the North. Sea: history and patterns. Bull Inst R Sci Nat Belg Biologie 67(Suppl):15-28

Smeenk C, Addink MJ (1993) Sighting of a group of sperm whales (Physeter macrocephalus) in Dutch waters, with historical notes and the possible Orkney connection. Lutra $36: 25-29$

Smith SC, Whitehead H (1993) Variation in feeding success and behaviour of Galapagos sperm whales (Physeter macrocephalus) as they relate to oceanographic conditions. Can J Zool 71:1991-1996

Sundet JH (1985) A short review on the biology and fishery of the squid Todarodes sagittatus. ICES CM 1985/K:44

Tarasevich MN (1963) Materialy po pitaniyu kashalotov severnoi chasti Kuril'skikh vod (raion Paramushira, Onekotana, Shiashkotana) (Data on feeding of sperm whales in the northern area of Kurile waters [region of Paramushir, Onekotan and Shiashkotan]). Tr Inst Okeanol Akad Nauk SSSR 71:195-206

Turner $W(1871)$ On the capture of a sperm whale on the coast of Argyleshire, with a notice of other specimens caught on the coast of Scotland. Proc R Soc Edinburgh 7 : 365-370

Viale D, Verneau $N$, Tison $Y$ (1992) Stomach obstruction in a sperm whale beached on the Lavezzi islands: macropollution in the Mediterranean. J Rech Oceanogr 16:100-102

Voss NA (1969) A monograph of the Cephalopoda of the North Atlantic. The Family Histioteuthidae. Bull Mar Sci 19:713-867

Voss NA (1985) Systematics, biology and biogeography of the cranchid cephalopod genus Teuthowenia (Oegopsida). Bull Mar Sci 36:1-85

Whitehead $H$ (1996) Variation in the feeding success of sperm whales: temporal scale, spatial scale and relationships to migrations. J Anim Ecol 65:429-438

Whitehead H, Arnbom T (1987) Social organisation of sperm whales off the Galapagos Islands, February-April 1985. Can J Zool 65:913-919

Whitehead H, Papastavrou V, Smith SC (1989) Feeding succes of sperm whales and sea-surface temperature off the Galapagos Islands. Mar Ecol Prog Ser 53:201-203

Wiborg KF (1979) Gonatus fabricii (Lichtenstein), en mulig fiskeriressurs i Norskehavet (Gonatus fabricii [Lichtenstein], a possible fishery resource in the Norwegian Sea). Fisken Havet 1979:33-46 (in Norwegian with English abstract)

Wiborg KF, Beck IM (1984) The squid Todarodes sagittatus (Lamarck) investigations in Norwegian coastal and bank waters, July 1983-January 1984, and west of the British Isles, March-April 1984. ICES CM 1984/K:20

Wiborg KF, Gjøsæter J, Beck IM (1982) The squid Gonatus fabricii (Lichtenstein). Investigations in the Norwegian Sea and western Barents Sea 1978-1981. ICES CM 1982/K:31

Wiborg KF, Beck IM, Gjøsæter J (1984) The squid Gonatus fabricij (Lichtenstein). Investigations in the Norwegian Sea and western Barents Sea 1982-1983. ICES CM 1984/K:19

Submitted: October 23, 1998; Accepted: December 23, 1998 Proofs received from author(s): June 29, 1999 